\title{
Exploring Local Wisdom in Buginese Ethnics: Language Politeness Phenomena of Tau Soppeng
}

\author{
Fiptar Abdi Alam ${ }^{1}$ and Al-Muthmainnah Al-Muthmainnah ${ }^{2}$ \\ ${ }^{1}$ Guidance and Counseling Study Program, STKIP Muhammadiyah Barru, Indonesia \\ ${ }^{2}$ English Education Study Program, STKIP Dampal Selatan, Indonesia \\ fiftar.alam@stkipmb.ac.id
}

\section{ARTICLE HISTORY \\ Received : 2020-03-06 \\ Revised : 2020-03-15 \\ Accepted : 2020-04-20}

\section{KEYWORDS}

Local wisdom

Politeness

Linguistic politeness

\begin{abstract}
The objectives of this research are to explore and to reveal the forms and the characteristics of linguistic politeness, politeness strategies, and the realization of local wisdom found among Soppengese (Tau Soppeng), one particular people of Buginese ethnics. This research applied ethnolinguistics viewed from pragmatics, semiotics, and politeness theories. To capture the data, this study used purposive sampling and snowball among native in Soppeng regency which agrees to be a part of this study. The method used is the method of listening with free engaged, recording, documentation, elicitation technique, and interview. The results of this research show the characteristics and the forms of linguistic politeness through marked morphemes, prefix $(t a)$, suffix pronouns (ta, ki, ni), honorific vocabularies (pung, andi, daeng), lexemes (iye, tabe, taddampengenga), maxims of politeness principles (generosity, approbation, modesty, sympathy), and four strategies of linguistic politeness (bald on record, positive, negative, off-record strategy). In addition, this study also found the realisation and the implication of local wisdom as a primary value such as ethics and language politeness, self-image, courage, solidarity, and cooperation.
\end{abstract}

\section{Introduction}

Politeness behaviour is very closely related to the culture and language of an ethnic group. Both cannot be separated between one another. According to Fromkin, Rodman, \& Hyams (2003), language is a reflection of culture. Otherwise, culture is a value, a principle that can the truth is believed in the speakers of a language, and can be a guide in interacting and communicating. One of the ethnic cultures in Indonesia is the Soppeng Buginese community. There is no doubt that the Indonesian nation consisting of various ethnicity in this archipelago is rich in values noble personality as a value inheritance past culture. Abdulrahman (2007) stated that the accumulation of these noble values symbolizes and can strengthen the identity of the Indonesian people, as a multilingual country, and has a polite and highly civilized society. This legacy of noble values strengthens the brotherhood of Indonesia, which is multi-ethnic.

However, in this era of openness and reform, the linguistic politeness of Indonesian tends to decline. That matter considered in the Bugis community, including Soppeng Buginese. Starting from that reality, this form of politeness in the language needs to be studied more in-depth and comprehensive, so that can be a material for character formation based on local wisdom. This effort is expected can trigger the strengthening of identity again and language manners, especially in the Bugis community based on the culture they have.

The focus of this research study are: (1) the characteristics of the form of linguistic politeness in Soppeng Buginese society, (2) the forms of politeness strategy represented by Soppeng Buginese community in interacting based on communication and situation context, (3) principle realization of local wisdom value on politeness strategies of Soppeng Buginese society. Watts (2003) reveals that the word 'polite' comes from the English word, which is equivalent to the Latin politus means smooth (polish). Whereas according to Cumming (2005), politeness is selfcontrol and social control. The characteristic of a person's polite behaviour is equivalent to social accuracy, or acceptance of behaviour in social interactions context.

In Bugis language, politeness is called pangadereng or ampe madeceng (Abdulrahman, 2007). Studying the phenomena of the Buginese in term of the linguistic politeness is inseparable from the review of the meaning of speech related to events and speech situation, and interpretation of meaning associated with cultural norms and principles. 
Therefore, in this research, the meaning of siri' culture and the cultural meaning of 3S (sipakatau $=$ glorify each other, sipakaraja $=$ respect each other sipakainge' $=$ remind each other) are seen as central values in the Buginese society.

In his research, Achmad (2012) found that the politeness strategies applied in Buginese society communication have implications for the principle of the cultural value of siri' in the Buginese community. The realization of politeness is manifested in the cultural values of sipatangngari $=$ deliberation, sipakaraja $=$ mutual respect, sipaku $=$ mutual glorify (3S) on the language behaviour of Buginese people. Lakoff (1973) proposed a formula of linguistic politeness by basing self on pragmatic competence through two elements, namely 'be clear' and 'be polite'. Firstly, the element of 'be clear' is based on the cooperation principle, which covers:

a) Quantity maxim: giving sufficient information as needed

b) Quality maxim: saying what is believed right

c) Relevant maxim: information conveyed is relevant

d) Manner maxim: not contain imprecise information

Secondly, the element of 'be polite' covers:

a) Not impose to the interlocutor

b) Giving option

c) Showing hospitality and familiarity

Leech (1983) formulated the principle of politeness by focusing more on pragmatics. In his theory, two pragmatic systems are known, namely text rhetoric and interpersonal rhetoric. Text rhetoric refers to the clarity principle, economy principle, and expressivity principle. While interpersonal rhetoric refers to interpersonal relationships between speech participants. In this theory, Leech formulated the maxims which are aimed at the speech partners, namely tact maxim, generosity maxim, approbation maxim, agreement maxim, and sympathy maxim. The basic idea of tact maxim is that each participant must benefit themselves and maximize the advantages of others. Commanding with an interrogative sentence is considered more polite than using the command line, for example, "Could I interrupt you for a half-second - what was the website address?"

In generosity maxim, the speakers said an utterance that minimizes profit for self. For example, "Let me wash your clothes too. I have the same thing to be washed, really." This utterance is considered polite because it minimizes the benefit for the speaker. Approbation maxim is expressed by minimizing the expression of dispraise of others. A person will be considered polite if the person maximizes praise to others or the hearer. For example, "I heard your English just now; your pronunciation is very good". Modesty maxim is self-centred. This maxim means maximizing dispraise of self. For example, "I don't think I will do it well. I am still learning". This utterance is considered polite because the speaker maximizes dispraise of self.

Agreement maxim is emphasized that the speaker is able to develop an agreement to the speech partners. For example, "Good idea, I will wait for you at the restaurant". This conversation shows that the speaker is able to build their agreement so that they will be polite to each other.

In sympathy maxim, it is expected that the participant can maximize sympathy among people. Antipathy toward others will be considered as impoliteness. For example, "I take pity on hearing you didn't pass the exam."

Studies on politeness based on Leech's theory have been carried out by several researchers. One of the studies was carried out by Eshghinejad \& Moini (2016) to investigate the politeness principles used in text messaging between teacher and EFL students. They found that teachers used politeness principles in text messaging. Results of that study also showed no significant difference between male and female EFL learners in applying politeness principles in communication.

Another study was conducted by Haryanto, Weda, $\&$ Nashruddin (2018). They researched to find out the politeness principles used by EFL teachers during the classroom interaction, and the implication of politeness principles toward the teaching-learning process. The result of the study showed that the politeness principle creates togetherness between the teacher and the students, builds respect behaviour of the students, and creates cooperating interaction between the teacher and the students.

Lakoff's theory and Leech's theory were then perfected by Brown \& Levinson (1987). The core of the theory is to save the face of the interlocutor (facethreatening act). The speaker selects the utterances based on three social factors, namely social relations, the strength of symmetric relationships, and the scale of emphasis level. Furthermore, Brown \& Levinson (1987), in their analysis, stated that politeness involves people showing an awareness of other people's face wants. Face refers to our public selfimage. Brown and Levinson formulated the politeness principles into five strategies, namely bald on record strategy, positive politeness strategy, negative politeness strategy, off-record strategy, and do not do the FTA. Moreover, research on politeness based on the theory of Brown \& Levinson had been conducted by Sulu (2015), who investigated an interaction between English learners and a native Englishspeaking teacher.

Therefore, the study aims to see whether the effects of politeness strategies differ when students and teacher do not share the same culture and native 
language. The researcher observed and tape-recorded two hours of classes. The research findings show that politeness exists in that EFL classroom helps students to have positive feelings towards the lesson and motivates them to participate more in classes. Nevertheless, According to Mattulada (1997), the cultural practitioners view that the Indonesian nation, which consists of various ethnicity is rich in values of noble personality as a value of the past inheritance. In Bugis ethnic culture, the phenomenon of linguistic politeness can be observed comprehensively through the meaning of siri' culture. The great value is elaborated in three cultural subsystems, namely sipakatau, sipakaraja, sipakainge'.

\section{Method}

This research is located in Soppeng Regency, with the characteristic population of the Bugis language of Soppeng community in daily communication interaction. Sample of this research includes discourse data or speech-language that has been obtained and the results of interviews about realization and value implications of cultural meanings. In collecting data, the techniques used were purposive sampling and snowball. The method used is the method of listening with free engaged, recording, documentation, elicitation technique, and interview. The data analysis technique used was componential utterance (Brown \& Yule, 1983) that is investigating the interpretive meaning (pragmatic) and the value of utterances based on context and situation in terms of social semiotic aspects.

\section{Findings}

\subsection{The Characteristics of the Form of Linguistic Politeness among To Soppeng}

The forms and the markers of linguistic politeness in Soppeng Buginese were found in two levels, namely morphology level and syntax level. In the level of morphology, it can pay close attention to the speech with the topic "ordering".

\section{Ta-pattama-ni motorok-ta ko ilaleng bola-e}

(Just put your motorcycle in the house)

Pattama-ni motorok-mu ko ilaleng bola-e

(Just put your motorcycle in the house)

The utterances "Ta-pattama-ni" (1), and "Pattamani" (2), have the same meaning, namely "Just put in". The difference is that "Ta-pattama-ni" begins with morpheme $/ \mathrm{ta} /=$ you, which is imperative as a form of linguistic politeness in the Bugis language. In the other hand, "Pattama-ni" without morpheme /ta/, this shows a less impolite linguistic formula.

Similarly, it can be observed on the use of enclitic morpheme /ta/ in "motorok-ta" (1) = your motorcycle, which is a sign of politeness. In number (2), the enclitic morpheme /mu/ in "motorok-mu" seems impolite. Thus, these two morphemes can be a formula hint of linguistic politeness in Buginese. The same case is found in the following utterances.

Aleng-a yatu colok-e, loka mattunu

(Give me the lighter, I want to burn)

Taleng-a yatu colok-e, loka mattunu

(Give me the lighter, I want to burn)

Another feature of the marker of linguistic politeness in Buginese is the use of /iye/ in initiating an utterance.

\section{Iye matei gare kasi' di! \\ Nappa toi uwisseng}

(Pity, I hear that he's dead! I also just found out)

The use of morpheme /iye/ is the realization of the cultural value of respects each other (sipakaraja). Another similar example is the use of words tabe', and taddampengenga, which mean excuse me, and forgive me. For example, in an utterance:

\section{Taddampengenga Uwak, engkaro palopekku ri seddeta}

(I'm sorry, Uncle, that's my pen beside you)

The use of morpho-phonemic /ki/ in "leppakki" from the basic word "leppang" is a marker of politeness in bugis language. If $/ \mathrm{ki} /$ is substituted with /ko/ becomes "leppako", the formulation is not polite when addressed to people who are valued. Leppakki and leppakko have the same meaning, namely "come on drop by", but "leppakki" is polite utterance, while "leppakko" is impolite.

In the syntactic level, the marker of linguistic politeness can be observed in an example as follows:

Bosi ladde'si maka cekke i-sedding, colok-mi utiwi

(Heavy rain again, very cold, I only brought a match)

\section{Taddampenge-nga Daeng, de gaga tole u-tiwi.}

(I'm sorry, Brother, I don't bring cigarettes)

Pragmatically, the meaning of the expression (7) is to ask for cigarettes. The listener can understand the meaning of the utterance. Then he said that he also didn't carry cigarettes (8).

The form and features of linguistic formulas can be in terms of the Bugis language phenomenon based on distance and social status, influence the phenomena of speech variation.

Oppana nappammula acara-e ro Pammu? (9)

(When will the event begin, Pammu?) 
Iye, de to gaga padisenge-ku pung,kade oppannapi

(I also don't know when it will start, Sir)

From the discourse above, it is known that the speaker of (10) has a higher status than the speaker of (9). The linguistic formula in the utterance (9) is very official, using off-record strategy, or indirectly, and also use lexemes that indicate courtesy of acceptable language, namely: iye and pung.

\subsection{The Forms of Politeness Strategy Represented by Buginese Community}

Firstly, tact maxim that each participant said to maximize the profits of others. It can be seen in the examples (1), (4), (6), and (10). Another example:

Iye ta-alani-mai pangelli bale-na

(Please take money to buy fish)

The second is the generosity maxim. The indicators of this maxim are expressive and assertive. The expressive utterance has an expressing function or notifies attitude a psychological, tangible statement illocution is like saying thank, praise, and express condolences. Assertive speech involves the speaker at the truth of propositions expressed, for example, stating, complaining, suggest, and report, and so on. It can be listened to the following discourse:

\section{Sukkuru ladde-ka apa engka-ki kasih}

(I am very grateful because you came)

\section{Iye, majjappa-jappa-ki amaure}

(Wish you always be healthy, Uncle)

The discourse above shows cooperation in addition to using lexeme /iye/, and enclitic pronoun /ta/.

\subsection{Local Wisdom's Principle Value}

Paying attention to the context of realization and implications of the concept of Siri' and the subsystems (3S), the values of these cultural principles are stated in 6 basic principles, namely:

a) Strengthening identity

b) Courage and self-image

c) Maintaining human dignity, existence and existence

d) Politeness and ethics in social interaction

e) Solidarity and cooperation

f) The principle of honesty, responsibility, responsibility, and accountability

These have an impact in the realization of the conception of fundamental values, namely the formation of values such as the value of determination, namely motivation and outlook life, the value of courage, which is value emotional temperament in maintaining pride, solidarity value, that is the value of mutual cooperation, and the value of politeness language, language skills based on Buginese ethnic cultures.

\section{Conclusion}

From the results of research and discussion, researchers conclude that the first is relating to linguistic formulas, it was found in politeness markers of Soppeng Buginese were very varied. The forms and the markers of linguistic politeness in Soppeng Buginese were found in two levels, namely morphology level and syntax level. Soppeng Buginese linguistic politeness can be reflected based on values of siri' and $3 \mathrm{~S}$ as central values, through the creation of variations or variations speech as a politeness strategy, which is influenced by factors of speech participant status, situation and context. Realization of Soppeng Buginese linguistic politeness associated with pragmatics found in some maxims: tact maxim, generosity maxim, and modesty maxim. Found on four the strategies: bald on record, positive politeness, negative politeness, off-record. The implication of local wisdom as a primary value such as ethics and language politeness, self-image, courage, solidarity, and cooperation.

\section{References}

Abdulrahman. (2007). Pelestarian kearifan lokal melalui pewarisan bahasa Bugis. Paper presented at the Kongres Internasional Bahasabahasa Daerah Sulawesi Selatan, Makassar.

Achmad, S. (2012). Strategi kesopanan berbahasa masyarakat bugis pinrang provinsi sulawesi selatan. Bahasa dan Seni: Jurnal Bahasa, Sastra, Seni, dan Pengajarannya, 40(1).

Brown, \& Yule, G. (1983). Discourse Analysis. Cambridge: Cambridge University Press.

Brown, P., Levinson, S. C., \& Levinson, S. C. (1987). Politeness: Some universals in language usage (Vol. 4). Cambridge university press.

Cumming, L. (2005). Pragmatics: A Multidisciplinariy Perspective. Edinburgh: Hewer Text Ltd. .

Eshghinejad, S., \& Moini, M. R. (2016). Politeness strategies used in text messaging: Pragmatic competence in an asymmetrical power relation of teacher-student. SAGE Open, 6(1), 2158244016632288.

Fromkin, V., Rodman, R., \& Hyams, N. (2003). An Introduction to Language. USA: Michael Rosenberg.

Haryanto, H., Weda, S., \& Nashruddin, N. (2018). Politeness principle and its implication in EFL classroom in Indonesia. XLinguage" european Scientific Language Journal", 11(4), 90-112. 
Lakoff, R. (1973). The logic of politeness; or minding your ps and qs Papers from the 9th Regional Meeting of the Chicago Linguistic Society. Chicago: Chicago Linguistic Society, 292-305.

Leech, G. N. (1983). Semantics 3: Speech Act. New York: Academic Principles of Pragmatics.

Mattulada. (1997). Kebudayaan Bugis Makassar. In Koentjaraningrat (Ed.), Dalam Manusia dan Kebudayaan di Indonesia. Jakarta: Djembatan.

Sulu, A. (2015). Teacher's politeness in EFL class. Intenational Online Journal of Education and Teaching, 2(4), 216-221..

Watts, R. J. (2003). Politeness. Cambridge University Press. 